\title{
AS PROJEÇÕES DA VIOLÊNCIA DOMÉSTICA: UM ESTUDO A PARTIR DA INTERFACE ENTRE DESENVOLVIMENTO ECONÔMICO E DESENVOLVIMENTO HUMANO
}

\author{
PROJECTIONS OF DOMESTIC VIOLENCE: A STUDY FROM THE INTERFACE BETWEEN \\ ECONOMIC DEVELOPMENT AND HUMAN DEVELOPMENT
}

\author{
Fernando de Brito Alves ${ }^{1}$ \\ Gabriela dos Santos Paixão ${ }^{2}$ \\ Layana Mara Laiter Martins ${ }^{3}$
}

\section{RESUMO}

A violência doméstica e familiar contra a mulher é um problema afeto a todos os domínios da esfera social. No entanto, raramente o tema é trabalhado à luz dos desdobramentos que transcendem os limites da vida privada da vítima. A violência perpetrada contra a mulher possui raízes em concepções e valores primitivos que replicam a ideia da manutenção da mulher em papéis estereotipados ligados à desigualdade de gênero e em posições hierarquicamente estabelecidas. Assim, com o objetivo de investigar as projeções da violência doméstica na sociedade, o presente estudo, pautado no método de pesquisa dedutivo, busca demonstrar o liame estabelecido entre violência doméstica, desenvolvimento econômico e desenvolvimento humano, identificando-se a parcela de impacto da violência doméstica no desenvolvimento econômico do país, com base nos custos gerados pela violência doméstica ao orçamento do Sistema Único de Saúde e na sua interferência no mercado de trabalho e na vida laborativa da mulher vítima. Ao considerar as implicações do progresso econômico no investimento em áreas essenciais do desenvolvimento humano, e identificar a associação intrínseca entre violência doméstica e desigualdade de gênero, a pesquisa permite concluir que as projeções adjacentes à violência doméstica têm impacto significativo sobre o desenvolvimento econômico e humano do país.

Palavras-chave: Desenvolvimento econômico. Desenvolvimento humano. Mercado de trabalho. Desigualdade de gênero. Violência doméstica.

\footnotetext{
${ }^{1}$ Advogado. Doutor em Direito pela Instituição Toledo de Ensino - ITE / Bauru-SP. Mestre em Ciência Jurídica pela Universidade Estadual do Norte do Paraná - UENP. Graduado em Filosofia pela Universidade do Sagrado Coração e graduado em Direito pela Faculdade Estadual de Direito do Norte Pioneiro. Atualmente é Assessor Jurídico da UENP, Editor da Revista Argumenta, Coordenador do Programa de Pós-graduação (Mestrado e Doutorado) em Ciência Jurídica (2014-2022). Realizou estágio de pós-doutorado no Ius Gentium Conimbrigae da Faculdade de Direito da Universidade de Coimbra (2013-2014), Visiting researcher na Universidad de Murcia (2019). Afiliação: Universidade Estadual do Norte do Paraná (UENP) Lattes: http://lattes.cnpq.br/1975997868167667 ORCID: https://orcid.org/00000001-8917-4717.e-mail:fernandobrito@uenp.edu.br

${ }^{2}$ Mestranda no Programa de Pós-Graduação Stricto Sensuem Ciência Jurídica da Universidade Estadual do Norte do Paraná (PPGCJ/UENP)/Área de Concentração: Teorias da Justiça: Justiça e Exclusão. Linha de Pesquisa: Estado e Responsabilidade: Questões Críticas. Bacharela em Direito pela Faculdade de Direito da Alta Paulista (FADAP). Advogada. Afiliação: Universidade Estadual do Norte do Paraná (UENP). Lattes: http://lattes.cnpq.br/470 0195820138581 ORCID: https://orcid.org/0000-0001-6873-6741. e-mail: gabrielapaixao_@hotmail.com.

${ }^{3}$ Mestranda no Programa de Pós-Graduação Stricto Sensu em Ciência Jurídica da Universidade Estadual do Norte do Paraná (PPGCJ/UENP)/Área de Concentração: Teorias da Justiça: Justiça e Exclusão. Linha de Pesquisa: Estado e Responsabilidade: Questões Críticas. Especialista em Direito do Trabalho e Previdenciário pela Universidade do Norte do Paraná (UNOPAR). Bacharela em Direito pela Universidade Estadual do Norte do Paraná (UENP). Advogada bolsista do NUMAPE/UENP. Afiliação: Universidade Estadual do Norte do Paraná (UENP) Lattes: http://lattes.cnpq.br/5154658195052516 ORCID: https://orcid.org/0000-0003-2186-5938 E-mail: layanalaiter@gmail .com.
} 


\begin{abstract}
Domestic and family violence against women is a problem related to all the areas of the social sphere. However, the theme is rarely approached according to the effects that transcend the limits of the victim's private life. The violence perpetrated against women is rooted in conceptions and primitive values that replicate the idea of maintaining women in stereotyped roles linked to gender inequality and in hierarchically established positions. Thus, in order to investigate the projections of domestic violence in society, the present paper, based on the deductive research method, seeks to demonstrate the link established between domestic violence, economic development and human development, identifying the portion of the impact of domestic violence on the country's economic development, based on the costs generated by domestic violence to the budget of the Unified Health System and its interference in the labor market and in the victim's professional life. When considering the implications of economic progress for the necessary investment in essential areas of human development, and identifying the intrinsic association between domestic violence and gender inequality, the research permit to conclude that the projections adjacent to domestic violence have a significant impact on the economic and human development of the country.
\end{abstract}

Keywords: Economic development. Human development. Job market. Gender inequality. Domestic violence.

\title{
INTRODUÇÃO
}

Estimar as consequências oriundas da violência doméstica e familiar contra a mulher em países em desenvolvimento como o Brasil é um desafio, uma vez que a matéria raramente é tratada com a amplitude e a profundidade exigidas. Abordar a temática como algo inerente ao foro íntimo da mulher, e, portanto, limitado às consequências na esfera privada, faz com que os agentes políticos, a sociedade e as instituições, de um modo geral, não enxerguem o problema com a dimensão que realmente possui, restando ignoradas diversas implicações de interesse compartilhado.

Nesse contexto, o estudo que ora se descortina tem por objetivo geral situar a violência doméstica na pauta das discussões sociais na condição de um problema de viés público, de responsabilidade da sociedade e do Estado, e que ostenta a capacidade de atingir a vida de todos os que integram a comunidade, mesmo quando não envolvidos diretamente na prática de violência contra a mulher. Logo, a proposta é vincular a violência ao desenvolvimento econômico e ao desenvolvimento humano do país, duas importantes e pouco exploradas perspectivas de impacto da violência, e que necessitam ser investigadas.

O raciocínio a ser desenvolvido ao longo da pesquisa parte da percepção de que a mulher, em situação de violência doméstica, por vezes encontra barreiras que dificultam ou mesmo obstam a oportunidade de exercer atividades profissionais fora de casa, ficando à margem do mercado de trabalho e, em razão disso, acaba se tornando financeiramente dependente do seu companheiro. Em 
outros casos, em virtude das agressões sofridas, a mulher vítima não consegue preservar as capacidades físicas ou psicológicas necessárias à manutenção do seu emprego, perdurando o ciclo da violência e dificultando a sua emancipação. Em ambos os casos, a renda que a mulher deixa de auferir deixa também de movimentar a economia do país. Na mesma perspectiva, os reflexos da possível queda em sua produtividade no trabalho, e do absenteísmo provocado pela violência, têm impactos sobre o mercado laborativo e sobre o status da mão de obra feminina neste setor.

Sendo o Produto Interno Bruno (PIB) a soma de todos os bens e serviços finais produzidos por um país, é bastante claro que a violência doméstica, com os seus diferentes custos para o Estado, é um dos fatores que define este montante. $\mathrm{O}$ impacto da violência no desenvolvimento econômico faz com que o país deixe de investir em educação, saúde e segurança pública, áreas intrinsecamente associadas ao desenvolvimento humano. E é nesse sentido que a presente pesquisa busca demonstrar o liame existente entre violência doméstica, desenvolvimento econômico e desenvolvimento humano.

Assim, a partir do método dedutivo e do procedimento de pesquisa bibliográfica, o presente estudo visa investigar a violência doméstica com a profundidade necessária para evidenciar as diversas facetas que impactam de forma gravosa os domínios da vida pública e privada. Para tanto, o trabalho está estruturalmente dividido em três partes: busca-se, na primeira parte, definir a violência doméstica e familiar contra a mulher, empregando maior ênfase à Lei n. ${ }^{\circ} 11.340 / 2006$, na qualidade de aparato jurídico apresentado pelo Estado para coibir e punir a prática de violência doméstica no Brasil. Na sequência, abordam-se todas as formas de violência perpetradas contra a mulher e suas correspondências penais.

Em seguida, na segunda parte do trabalho, a violência doméstica é tratada sob a perspectiva econômica, oportunidade em que são demonstrados os custos que a violência traz para o Sistema Único de Saúde (SUS), bem como o seu impacto no PIB. As projeções da violência doméstica sobre a mulher e sobre o mercado de trabalho também são abordadas, delineando-se os aspectos que definem padrões dentro do mercado de trabalho e que limitam o avanço da economia. Em razão desses padrões e da discriminação em potencial, a pesquisa também aborda as ações do Estado para proteger o emprego de vítimas de violência doméstica. Por fim, na terceira e última parte, o estudo se destina à relação entre violência doméstica, desigualdade de gênero e desenvolvimento humano. $O$ foco é expor a violência doméstica como óbice ao desenvolvimento econômico e, consequentemente, ao desenvolvimento humano, e como fonte para o aprofundamento das disparidades de gênero e para a perpetuação das desigualdades no país. 


\section{VIOLÊNCIA DOMÉSTICA E FAMILIAR CONTRA A MULHER}

O conceito de violência contra a mulher surgiu "em meio a uma experiência política inovadora na década de 80 em que, ao lado de práticas de sensibilização e de conscientização, militantes feministas organizadas em grupos atendiam mulheres que sofriam com violência" (GREGORI, 2004, p. 250). Assim, a violência contra a mulher foi uma expressão elaborada a partir de uma compreensão particular acerca da opressão sofrida pelas mulheres no patriarcalismo, sintonizada com as discussões feministas em cenário internacional.

Consoante asseverado por Carneiro e Fraga (2012, p. 370), "no decorrer da história, a mulher carregou o estigma de sujeito com potencialidades reduzidas frente à figura masculina", e esse fator é relevante e deve ser levado em consideração quando do estudo da violência contra a mulher, "uma vez que esse mito, construído social e culturalmente, ainda encontra-se arraigado na sociedade nos dias atuais" (CARNEIRO; FRAGA, 2012, p. 370).

Dada a construção equivocada da figura da mulher no decorrer do processo histórico, privilegiando-se a figura masculina e valorizando sobremaneira o papel desempenhado pelo homem em sociedade em detrimento da condição feminina que ficara relegada à subalternidade, tem-se que a violência perpetrada contra a mulher resulta de uma relação baseada no gênero. ${ }^{4}$

Nessa perspectiva, a Convenção de Belém do Pará - Convenção Interamericana para Prevenir, Punir e Erradicar a Violência contra a Mulher - instituiu, em 1994, um novo conceito de violência contra a mulher sob o enfoque do gênero, entendendo ser "qualquer ato ou conduta baseada no gênero, que cause morte, dano ou sofrimento físico, psicológico e sexual à mulher, tanto na esfera pública como na privada." (grifo nosso).

Percebe-se, então, que manter a mulher em papéis estereotipados ligados ao seu gênero, é, na maioria das vezes, o motivo da violência, uma vez que o agressor ou a agressora, utiliza-se da força para manter a vítima presa aos papéis que a sociedade impõe. E esta imposição se dá de maneira preconceituosa, alicerçada em concepções e valores primitivos que foram sendo passados de geração em geração, e em uma relação hierarquicamente estabelecida e historicamente sacramentada, “configurando modelos patriarcais de família, onde o homem detém o poder sobre a mulher, dominando-a e oprimindo-a." (CARNEIRO; FRAGA, 2012, p. 372).

\footnotetext{
${ }^{4} \mathrm{O}$ conceito de gênero existe em razão das desigualdades históricas, econômicas e sociais entre homens e mulheres e do modo como eles se relacionam, naturalizando um padrão desigual, que importa a submissão da mulher ao homem. (SCARANCE, 2015 p. 50). Sendo gênero aquilo que diz respeito à construção social do que é ser homem e do que é ser mulher em uma sociedade (AZAMBUJA; NOGUEIRA, 2007, p. 102).
} 
E foi seguindo essa lógica que a Convenção de Belém do Pará de 1994, em seu Artigo 8, b, definiu a incumbência de os Estados-Partes adotarem, gradualmente, medidas visando à modificação dos padrões sociais e culturais relacionados à conduta de homens e mulheres, "a fim de combater preconceitos e costumes e todas as outras práticas na premissa da inferioridade ou superioridade de qualquer dos gêneros ou nos papéis estereotipados para o homem e a mulher, que legitimem ou exacerbem a violência contra a mulher".

Na continuidade das linhas conceituais sobre a violência doméstica e familiar contra a mulher, cumpre assinalar que, dentre os diplomas internacionais que abordam a temática, a Convenção de Istambul do Conselho da Europa de 2014 - o mais abrangente tratado internacional a versar sobre a matéria -, também contribuiu de forma significativa para a inserção e definição da questão do gênero nas discussões sobre a violência contra a mulher, e ampliou a definição de violência doméstica para:

[...] qualquer ato, omissão ou conduta que serve para infligir sofrimentos físicos, sexuais ou mentais, direta ou indiretamente, por meio de enganos, ameaças, coação ou qualquer outro meio, a qualquer mulher, e tendo por objetivo e como efeito intimidá-la, puni-la ou humilhá-la, ou mantê-la nos papéis estereotipados ligados ao seu sexo, ou recusar-lhe a dignidade humana, a autonomia sexual, a integridade física, mental e moral, ou abalar a sua segurança pessoal, o seu amor próprio ou sua personalidade, ou diminuir as suas capacidades físicas ou intelectuais.

Os textos jurídicos que dispõem sobre a violência doméstica buscam, logicamente, não apenas conceituá-la, mas trabalhar também na prevenção e na punição de tal prática. Uma resposta positiva à cultura de banalização da violência, e uma resposta necessária à proteção das mulheres vitimadas que sofrem diariamente com atos de recusa à sua dignidade, à sua integridade física e mental e com a violação de direitos inerentes à sua condição humana.

No entrecho dos inúmeros casos - denunciados e silenciados - de violência contra a mulher, desponta uma tarefa universalmente atribuída a cada Estado que, a seu modo, deve disciplinar o tema em âmbito interno. Nesse viés, cabe, portanto, discorrer a respeito da tutela jurídica dispensada à mulher vítima de violência doméstica no Brasil, e sobre como o tema vem sendo disciplinado no país.

\subsection{APARATO JURÍdiCo PARA COIBIÇÃo DA VIOLÊNCIA DOMÉSTICA NO BRASIL: A LEI MARIA DA PENHA - LEI N. 11. 340/2006}

$\mathrm{Na}$ esteira do que foi exposto nas linhas inaugurais do presente estudo, "O conceito de violência de gênero deve ser entendido como relação de poder de dominação do homem e submissão da mulher". O que indica que "a prática desse tipo de violência não é fruto da natureza, mas sim do processo de socialização das pessoas." (TELES; MELO, 2013, p. 18). Ocorre, porém, que a banalização e 
invisibilidade da prática da violência em âmbito doméstico permitiram que a sociedade justificasse a agressividade do homem como sendo algo biológico.

E foi neste cruel contexto, estruturada sobre a interpretação das questões de gênero, que a Lei n. ${ }^{\circ} 11.340 / 2006$ - a Lei Maria da Penha ${ }^{5}$-, deu novos contornos para a violência naturalizada no país, levando à reflexão as suposições de que sua prática pode ser justificada pela inconstância emocional, personalidade agressiva, superioridade física, drogadição ou alcoolismo, mesmo sendo estes fatores que se adicionam às dinâmicas culturais que dão base aos comportamentos violentos. (LOPES; et al., 2016).

Criada com fins de assegurar o disposto no art. 226, $\S 8^{\circ}$ da Constituição Federal, a Lei Maria da Penha agrega em seu conteúdo o intento de criar mecanismos para coibir e prevenir a violência doméstica e familiar contra a mulher, trazendo, ainda, para o âmbito nacional, a aplicação das medidas de assistência e proteção às mulheres em situação de violência doméstica e familiar; medidas que estão contidas nos documentos internacionais (regionais e globais) que versam especificamente sobre o tema: a Convenção sobre a Eliminação de Todas as Formas de Discriminação contra a Mulher (1979), a Convenção Interamericana para Prevenir, Punir e Erradicar a Violência contra a Mulher (1994) e outros tratados internacionais ratificados pelo Brasil.

Considerando que a violência doméstica contra a mulher "ainda faz parte de uma realidade que assombra o público feminino, violando os seus direitos em diferentes cantos do planeta, nas mais variadas idades, etnias e estratos sociais" (CARNEIRO; FRAGA, 2012, p. 370), no Brasil, a Lei Maria da Penha desponta como um aporte jurídico de projeções teóricas, conceituais e de implicações práticas na realidade da vítima. Assim, entende-se que a Lei deu abertura a um novo panorama de proteção à mulher no país a partir da previsão da elaboração e do desenvolvimento de políticas públicas tendentes a resguardar a mulher "de toda a forma de negligência, discriminação, exploração, violência, crueldade e opressão". (Art. $3^{\circ}$, parágrafo $1^{\circ}$ da Lei n. ${ }^{\circ} 11.340 / 2006$ ), visando a garantia dos direitos humanos das mulheres no âmbito das relações domésticas e familiares.

Nota-se que para tratar de violência doméstica e familiar contra a mulher no Brasil, é necessário conhecer o conceito de violência de gênero, pois, embora ambas as violências versem sobre situações semelhantes, a violência doméstica é limitada no que se refere ao vínculo de afeto e ao ambiente em que se desenvolve.

\footnotetext{
${ }^{5}$ A Lei n. ${ }^{\circ} 11.340$ de 7 de agosto de 2006 ficou conhecida como "Lei Maria da Penha", em alusão e homenagem à farmacêutica bioquímica cearense chamada Maria da Penha Maia Fernandes, mulher vítima de violência doméstica, tendo sido também vítima de duas tentativas de homicídio. O caso Maria da Penha obteve repercussão internacional no ano de 2002, em razão de recomendação ao Estado brasileiro feita pela Comissão Interamericana de Direitos Humanos, referente à omissão e negligência do país na edição de normas e políticas voltadas à proteção da mulher. Símbolo de luta e sobrevivência, Maria da Penha se tornou uma referência na luta contra a violência doméstica no Brasil.
} 
Uma vez que o conceito de violência se sujeita a transformações sociais, culturais, históricas e jurídicas, a Lei n. ${ }^{\circ} 11.340 / 2006$, ressignificou condutas que há muito a sociedade havia legitimado. Em seu artigo $5^{\circ}$ a Lei configura violência doméstica e familiar como a agressão (ação ou omissão), contra a mulher (vítima certa), baseada no gênero (finalidade), em determinado ambiente (doméstico, familiar ou de intimidade). ${ }^{6}$

Desta forma, tem-se que a violência de gênero ocorre única e exclusivamente em decorrência da vítima ser mulher, podendo se desenvolver em qualquer ambiente, de tal modo que o agressor não precisa, necessariamente, ter vínculo com a ofendida. Em contrapartida, para que a Lei Maria da Penha incida sobre o caso, a relação entre vítima e agressor deve ser doméstica, familiar ou de afeto, conforme o Enunciado $n^{\circ} 2$ do FONAVID (Fórum Nacional de Juízas e Juízes de Violência Doméstica e Familiar contra a Mulher) estabelecendo que nos casos em que inexista a coabitação ou vínculo de afeto entre agressor e ofendida, "deve ser observado o limite de parentesco estabelecido pelos arts. 1.591 a 1595 do Código Civil, quando a invocação da proteção conferida pela Lei n. ${ }^{\circ}$ 11.340/06 decorrer exclusivamente das relações de parentesco.”

Embora os enunciados do FONAVID não sejam vinculantes, é majoritário o entendimento de que para a incidência da Lei Maria da Penha, o agressor e a vítima devem possuir um vínculo, senão de parentesco, de afetividade. Porém, após atenta análise da Pesquisa "Visível e Invisivel: a vitimização de mulheres no Brasil”, com sua $2^{\text {a }}$ edição publicada em $2019^{7}$, pode-se perceber que $76 \%$ das mulheres indicaram que os agressores são conhecidos (dos vínculos mais citados destacam-se o namorado, o cônjuge ou o companheiro como sendo os principais perpetradores, com 23,8\%), e que $21,1 \%$ foram sinalizados como vizinhos, ou seja, não possuem parentesco e, por vezes, nem vínculo de afeto, mas se valem da proximidade com a vítima para praticar a violência. Nesse contexto, vale a reflexão sobre a necessidade de se ampliar o entendimento dos operadores do Direito sobre a incidência da Lei, passando a levar em consideração todas as peculiaridades da violência contra a mulher.

Assim, são reconhecidas as contribuições positivas da Lei Maria da Penha na realidade da violência doméstica e familiar contra a mulher no Brasil. Considera-se, portanto, à luz das palavras de Carneiro e Fraga (2012, p. 393), "como mais uma conquista da mulher no espaço social e na histórica

\footnotetext{
${ }^{6}$ Art. $5^{\circ}$ Para os efeitos desta Lei, configura violência doméstica e familiar contra a mulher qualquer ação ou omissão baseada no gênero que lhe cause morte, lesão, sofrimento físico, sexual ou psicológico e dano moral ou patrimonial: I - no âmbito da unidade doméstica, compreendida como o espaço de convívio permanente de pessoas, com ou sem vínculo familiar, inclusive as esporadicamente agregadas; II - no âmbito da família, compreendida como a comunidade formada por indivíduos que são ou se consideram aparentados, unidos por laços naturais, por afinidade ou por vontade expressa; III - em qualquer relação íntima de afeto, na qual o agressor conviva ou tenha convivido com a ofendida, independentemente de coabitação. Parágrafo único. As relações pessoais enunciadas neste artigo independem de orientação sexual.

${ }^{7}$ O conteúdo completo da pesquisa realizada pelo Fórum Brasileiro de Segurança Pública, com o apoio do Governo do Canadá e do Instituto Avon, consta do Relatório disponível em: http://www.forumseguranca.org.br/wpcontent/uploads/2017/03/relatorio-pesquisa-vs4.pdf. Acesso em 20 abr. 2020
} 
luta feminina pela igualdade perante o homem, em todos os aspectos e ao longo dos tempos". Mas é preciso observar que, não obstante as contribuições e os avanços desta Lei, ainda persistem os prementes desafios para o enfrentamento da violência doméstica contra a mulher, a exemplo das dificuldades diárias na aplicação e na efetivação das ações preventivas, protetivas e punitivas abarcadas na Lei. Assim, a realidade mostra que um grande e significativo passo já foi dado, no entanto, essa mesma realidade prediz que ainda há um longo e árduo caminho a ser percorrido.

\subsection{DAS FORMAS DE VIOLÊNCIA PERPETRADAS CONTRA A MULHER}

A correta conceituação de violência doméstica é de extrema importância social. Para Maria Berenice Dias (2015) embora não seja a Lei a via adequada para emissão de conceitos, acertou o legislador ao linear os contornos do delito e determinar suas formas e âmbito de ocorrência, pois foi a vasta ignorância popular que acabou por condenar tal crime à invisibilidade.

Ocorre, porém, que a Lei Maria da Penha não contém um rol de crimes de violência doméstica, fazendo em seu art. $7^{\circ}$ apenas referências amplas e, por vezes, deficitárias das formas de violência (violência física, violência psicológica, violência sexual, violência patrimonial, violência moral) que uma mulher pode sofrer em decorrência do seu gênero, servindo para fins jurídicos apenas como mera ilustração, não sendo capaz de abranger todas as diversas, peculiares e complexas formas de violência que circundam os lares brasileiros.

[...] para se chegar ao conceito de violência doméstica é necessária a conjugação dos arts $5^{\circ}$ e $7^{\circ}$ da Lei Maria da Penha. Deter-se somente no art. $5^{\circ}$ é insuficiente, pois são vagas as expressões: "qualquer ação ou omissão baseada no gênero"; "âmbito de unidade doméstica"; "âmbito da família" e "relação íntima de afeto". De outro lado, apenas do art. $7^{\circ}$ também não se retira o conceito legal de violência contra a mulher. A solução é interpretar os arts $5^{\circ}$ e $7^{\circ}$ conjuntamente para, então, extrair o conceito de violência doméstica e familiar contra a mulher. Ou seja, violência doméstica é qualquer das ações elencadas no art. $7^{\circ}$ (violência física, psicológica, sexual, patrimonial ou moral) praticada contra a mulher em razão de vínculo de natureza familiar ou afetiva. (DIAS, 2015, p. 51)

Para Valéria Diez Scarence Fernandes (2015, p. 58) a opção do legislador em não tipificar as condutas na Lei n. ${ }^{\circ}$ 11.340/2006 foi acertada, uma vez que todas as formas de violência encontram um tipo penal correspondente no Código Penal, lembra ainda que a Lei Maria da Penha foi instituída de modo atemporal, não se vinculando às alterações da legislação material.

A violência física, tratada no inciso I do art. $7^{\circ}$ da referida Lei, consiste, genericamente, em causar danos à integridade física da mulher. Pode se manifestar por meio de tapas, puxões de cabelo, socos, empurrões e agressões com instrumentos, que, de acordo com as consequências e circunstâncias da situação, podem ser tipificadas como vias de fato, lesão corporal, tortura ou feminicídio. 
A contravenção penal de vias de fato, prevista no art. 21 do Decreto-Lei n ${ }^{\circ} 3.688 / 41$, configura o delito de agressão que não deixa vestígios físicos ou dano aparente à saúde. Sem ocupar o devido espaço nos casos de violência doméstica, o delito de vias de fato acaba sendo uma violência impelida à invisibilidade pela legislação, uma vez que agressões dolorosas podem não deixar marcas, ou estas podem desaparecer antes de a vítima ser submetida ao exame de corpo de delito. Se a situação de violência resulta em dano à integridade física ou à saúde da mulher, configura-se o crime de lesão corporal previsto no art. $129, \S 9^{\circ}$ do Código Penal.

Por fim, se "a violência não for interrompida por uma intervenção processual dotada de efetividade pode evoluir para um feminicídio.” (SCARENCE FERNANDES, 2015, p. 68), e, embora nem todos os casos evoluam para a morte, "não se pode negar que a maior incidência de mortes de mulheres é justamente na situação doméstica" (KATO, 2008, p. 268).

Porém, é comum que a violência contra a mulher não se inicie com a agressão corporal, estabelecido o ciclo da violência, o agente fragiliza a vítima com intensas ofensas morais e psicológicas, ao ponto de não existir mais resistência ou de a ofendida naturalizar a situação.

A violência psicológica subjuga a mulher e se mantém pela naturalização. Não consiste em um fato isolado, mas sim na forma com que o agressor se relaciona. É perigosa por ser, muitas vezes, imperceptível. "O comportamento típico se dá quando o agente ameaça, rejeita, humilha ou descrimina a vítima, demonstrando prazer quando vê o outro se sentir amedrontado, inferiorizado e diminuído [...]" (CUNHA; PINTO, 2008, p. 58).

Nas situações de violência [psicológica] doméstica, há inversão da culpa. O agressor faz a vítima crer que ela é a responsável pelo ato de agressão, porque descumpriu um dever ou falhou. E essa inversão marca a dominação psicológica que o homem estabelece prevalecendo-se dos papeis definidos socialmente como o responsável pelas decisões e estabilidade do lar. (SCARENCE FERNANDES, 2015, p. 83)

Dentre os atos que causam prejuízos à saúde psicológica, os tipos penais mais comuns são: i) perturbação da tranquilidade, previsto no art. 65 do Decreto-lei n ${ }^{\circ} 3.688 / 41$ - Lei das Contravenções Penais -; ii) constrangimento ilegal, com fundamento legal no art. 146 do Código Penal, consistindo em constranger alguém a fazer algo ou deixar de fazer mediante violência ou grave ameaça; iii) ameaça, o tipo mais comum e frequente de violência psicológica, tem previsão legal no art. 147 do Código Penal; iv) sequestro e cárcere privado, nos termos do art. 148 do Código Penal, acontece quando o agente priva a vítima de sua liberdade, solidificando a objetificação da mulher pela crença de que ela somente pode ir e vir com autorização de um homem. A Lei n. ${ }^{\circ} 11.340 / 06$, não descreve o verbo penal, mas trata do isolamento da ofendida, podendo ser caracterizado o sequestro e o cárcere 
privado; v) tortura psicológica, pode ser caracterizada como lesão corporal ${ }^{8}$ se importar em danos à saúde mental, como stress pós traumático ou alterações psíquicas (depressão) que se desenvolvem em razão da violência; vi) descumprimento de medida protetiva, previsto no art. 24-A (Incluído pela Lei n. ${ }^{\circ} 13.641$, de 2018).

A violência sexual foi definida pela Lei n. ${ }^{0} 11.340 / 06$ de forma atemporal e abrangente, de modo que são vários os tipos penais que podem incorrer como violência doméstica. São muitos os exemplos em que a ela pode se desenvolver: o crime de estupro (art. 213 do Código Penal, e para os casos de vítimas sem discernimento ou com vontade viciada incorre o art. 217-A), que consiste na prática sexual (ou ato libidinoso), mediante violência ou grave ameaça. Há, ainda, o crime de violação sexual mediante fraude, prevista no art. 218-A do Código Penal. A exploração sexual e prostituição (art. 227 do Código Penal) também podem ocorrer em âmbito doméstico ou decorrer de um vínculo de afeto.

Nota-se a evolução da legislação para acompanhar os casos emergentes da dinamicidade social. Tem-se que em um período histórico a mulher era obrigada perante a legislação a quitar o que era conhecido como "débito conjugal", não possuindo proteção específica aos crimes sexuais quando praticados pelo marido. A título de exemplo das modificações legislativas, Magalhães Noronha (1969):

As relações sexuais são pertinentes à vida conjugal, constituindo direito e dever recíproco dos que casaram. $\mathrm{O}$ marido tem direito à posse sexual da mulher, ao qual ela não pode se opor. Casando-se, dormindo sob o mesmo teto, aceitando a vida em comum, a mulher não se pode furtar ao congresso sexual, cujo fim mais nobre, é o da perpetuação da espécie. A violência por parte do marido não constituirá, em princípio, crime de estupro, desde que a razão da esposa para não aceder à união sexual seja mero capricho ou fútil motivo, podendo, todavia, ele responder pelo excesso cometido. (NORONHA, 1969, p. 100)

Em um dado momento da história, a própria legislação justificava o que hoje se considera como graves violações. A exigência constitucional de um código penal assentado na equidade não impediu que as mulheres fossem classificadas em honestas ou desonestas de acordo com seu recato sexual. Também se verifica como regra, que o casamento isentava a mácula decorrente da ofensa à honra da mulher que era vitimada por crime contra sua liberdade sexual. "[...] Assim, o casamento subsequente ao delito reconstruía o atributo da honestidade da mulher e restaurava sua honra - implicando o reverso que, diante da inexistência do casamento, tivéssemos o binômio criminoso/desonrada, reforçando o estereótipo em favor da mulher.” (LAVORENTI, 2007, p. 190)

\footnotetext{
${ }^{8}$ Enunciado $\mathrm{n}^{\circ} 18$ do COPEVID - Caso a violência doméstica praticada pelo suposto agressor gere danos à saúde psicológica da vítima, o Promotor de Justiça deverá requisitar a realização de perícia médica psiquiátrica para atestar as lesões à saúde, tais quais depressão, estresse pós traumático, síndrome do pânico, transtorno obsessivo compulsivo, anorexia, dentro outros, para posterior oferecimento de denúncia por crime de lesão à saúde psicológica $(\mathrm{CP}$, art. 129 , caput, $2^{\text {a }}$ parte, c.c. o $\S 9$ ou modalidade agravadas).
} 
Trazido o conceito de igualdade material e formal pela Constituição vigente, a liberdade sexual da mulher tornou-se um bem digno de tutela legislativa. Exemplo disso é a Lei n. ${ }^{\circ}$ 13.718/2018, que trata dos novos tipos penais da importunação sexual e a divulgação de cena de estupro ou de cena de estupro de vulnerável, cena de sexo ou nudez, sendo a pena aumentada de 1/3 (um terço) a 2/3 (dois terços) se o crime é praticado por agente que mantém ou tenha mantido relação íntima de afeto com a vítima ou com o fim de vingança ou humilhação. Nos casos de violação dos direitos relativos à concepção e maternidade, são comuns os relatos de parceiros(as), que impedem o uso de métodos contraceptivos. Tais condutas constituem constrangimento ilegal (art. 146 do Código Penal). Além disso, o aborto sem o consentimento da gestante e a esterilização cirúrgica em desacordo com a lei também encontram correspondência no Código Penal.

As várias formas de violência acarretam inúmeros prejuízos às incontáveis vítimas de violência doméstica, mas, na maioria das vezes, o fenômeno é analisado como um problema de esfera privada, de foro íntimo e capaz apenas de gerar complicações em ambientes e relações pessoais. A realidade, porém, é outra bastante distinta. Quando dispensada a devida atenção e reconhecida a complexidade, o fenômeno acaba por se mostrar como um entrave deveras gigantesco ao desenvolvimento social, cultural, econômico e, claro, pessoal.

\section{A VIOLÊNCIA DOMÉSTICA SOB O VIÉS ECONÔMICO}

Tratar de violência doméstica exige do pesquisador o entendimento de que determinado problema atinge todas as esferas sociais e que, embora as consequências sejam devastadoras para a mulher, os desdobramentos vão além da vida privada da vítima.

A violência doméstica não é um problema que afeta o âmbito privado. Ao contrário, se manifesta como símbolo mais brutal da desigualdade existente em nossa sociedade. Trata-se de uma violência que é dirigida às mulheres pelo fato de sê-las, por serem consideradas, por seus agressores, carentes de direitos mínimos de liberdade, respeito e capacidade de decisão. (ESPANHA, 2004, [n.p])

Entender a violência doméstica como um problema com consequências que atingem também a esfera pública, permite que se enxergue a questão com a completude exigida. Neste contexto, adotando uma perspectiva econômica, o Centro Nacional de Prevenção e Controle de Lesões do Departamento de Saúde e Direitos Humanos de Atlanta na Geórgia, Estados Unidos, realizou uma pesquisa no ano de 2003 que teve por objetivo calcular o custo da violência doméstica (tendo por referência o ano de 1995). Este estudo, por meio do levantamento de vítimas não fatais que utilizaram dos serviços de saúde, estimou que 5,3 milhões de mulheres acima de dezoito anos de idade foram 
vítimas de violência doméstica e dentre esse montante, 2 milhões ficaram feridas, sendo que 550.000 necessitaram de atenção médica. Concluindo, então, que os custos das consequências de um estupro, lesão corporal, perseguição e outras formas de violência excedem U\$ 4,1 bilhões de dólares apenas em serviços de assistência médica e saúde mental (NATIONAL CENTER FOR INJURY PREVENTION AND CONTROL, 2003, tradução nossa).

A pesquisa considerou apenas os gastos em serviços de saúde, mas o prejuízo é muito maior quando outras variáveis são adicionadas à equação, como o exemplo das crianças que são vítimas (diretas ou indiretas) da violência doméstica e têm tendência a não apresentar bons resultados escolares, aumentando o custo do Estado com professores e reforços, ou então as pensões por morte ou auxílios despendidos pelo INSS em casos de feminicídio ou lesões que invalidam mulheres.

[...] Em pesquisas, mulheres que sofreram VPI $^{9}$ relatam um estado de saúde significativamente pior quando comparado a mulheres que não sofreram abuso. Elas têm dificuldade para caminhar, as atividades diárias demandam mais esforços, sofrem de dor, perda de memória, tonturas e secreção vaginal. Elas também relatam níveis significativamente mais elevados de angústia emocional, pensamentos suicidas e tentativas de suicídio. (Ellberg; et al, 2008). Com base em estudos de países, a OMS (2013) também conclui que as mulheres que sofrem VPI são 16\% mais propensas a dar a luz a um bebê de baixo peso e, em algumas regiões, 1,5 vezes mais suscetíveis a contrair HIV e 1,6 vezes de ter sífilis quando comparadas a outras mulheres que não sofrem desse tipo de violência. Além disso, há consequências a longo prazo para a próxima geração que testemunhou a violência. As filhas são mais propensas a serem abusadas pelos parceiros e, seus filhos, a tornarem-se abusadores (Hindin et al 2008; WDR 2012, p. 152) (HOEFFLER; FEARON, 2014, p. 20, tradução nossa). ${ }^{10}$

Após a violência, a mulher utiliza o serviço de saúde em razão das lesões, mas de um único ato decorrem diversas outras consequências, como a depressão, ataques de pânico, problemas de memória, calcular quanto isso custa ao SUS é uma conta difícil de ser efetuada. Um bebê que nasce abaixo do peso necessita de cuidados muito específicos como a UTI neonatal e, embora não pareça, esse pode ser um custo decorrente da violência doméstica. Na mesma perspectiva, Nadine Gasman, representante da ONU Mulheres, ponderou que

\footnotetext{
${ }^{9}$ Violência por Parceiro Íntimo.

${ }^{10}$ Texto original: [...] In surveys women who suffered IPV report significantly poorer health when compared to nonabused women. The have difficulty walking, struggle with daily activities, suffer from pain, memory loss, dizziness and vaginal discharge. They also report significantly higher levels of emotional distress, suicidal thoughts and suicidal attempts (Ellsberg et al 2008). Based on country studies the WHO (2013) also concludes that women who suffer IPV are 16 per cent more likely to have a low birth weight baby and in some regions they are 1.5 times more likely to acquire HIV and 1.6 times more likely to have syphilis when compared to women who do not suffer partner violence. In addition there are long term consequences for the next generation that witnessed the violence. Daughters are more likely to be abused by their partners and their sons are more likely to become abusers themselves (Hindin et al, 2008; WDR 2012: 152).
} 


\begin{abstract}
A violência contra as mulheres é uma manifestação perversa fruto da discriminação e da desigualdade de gênero. Para além das consequências humanas imensuráveis que ela traz, tal violência impacta em elevados custos para os serviços de atendimento - incluindo a saúde, a segurança e a justiça. Investir na prevenção e na erradicação da violência contra as mulheres e meninas é muito menos custoso do que tem nos custado a falta de ação. (ONU, 2017)
\end{abstract}

Estima-se, portanto, que o custo da violência contra as mulheres represente $2 \%$ do produto interno bruto global, ou cerca de 1,5 trilhões de dólares (ONU, 2017). Segundo a pesquisa Conflict and Violence (2014), o homicídio de mulheres custa $0,31 \%$ do PIB na América Latina e $0,12 \%$ no resto do mundo (HOEFFLER; FEARON, 2014). Segundo Ribero e Sánchez (2005), a Colômbia perde, em média, 4,2\% do PIB anualmente, devido ao custo indireto da violência doméstica. Morrison e Biehl (1999) constatam que a violência doméstica custa $2 \%$ do PIB ao Chile. Porém, cabe ressalvar que cada um destes estudos adota uma metodologia diferente, tornando difícil compará-los.

O Brasil é um dos países que mais sofre com a violência doméstica, porém, a magnitude das consequências desse problema não pode ser aferida. Os custos para o sistema de saúde, a polícia, o poder judiciário, os órgãos de apoio à mulher, não pode ser precisado, pela falta de dados e em razão da complexidade do assunto. (OMS, 2002). No país, apenas no ano de 2017, mais de 221 mil mulheres procuraram delegacias de polícia para registrar episódios de agressão (lesão corporal dolosa) em decorrência de violência doméstica, número que pode estar em muito subestimado dado que muitas vítimas têm medo ou vergonha de denunciar (Fórum de Segurança Pública, 2018).

Uma pesquisa realizada pela Universidade Federal do Ceará em parceria com o Instituto Avon, constatou que a mulher em situação de violência doméstica perde em média 18 dias de trabalho por ano. O custo do absenteísmo estimado pela Pesquisa de Condições Socioeconômicas e Violência Doméstica e Familiar contra a Mulher (PCSVDF-Mulher) é de aproximadamente R\$1 bilhão de reais por ano à economia do país.

Segundo o estudo, que foi realizado no nordeste do Brasil, 12,5\% das mulheres empregadas nas capitais nordestinas sofreram algum tipo de violência doméstica nos últimos 12 meses, resultando em 219.109 mulheres, uma vez que segundo a PNAD Contínua (IBGE, 2016) estimou que aproximadamente 1.752.874 mulheres possuíam ocupação na época. "Logo, o número total de dias de trabalho perdidos devido ao absenteísmo (assumindo a média de 18 dias perdidos) causado pela violência doméstica somam 985.986 dias, ou quase 7,9 milhões de horas trabalhadas perdidas." (PCSVDF- Mulher, 2017, p. 12). Mulheres em situação de violência doméstica sofrem o impacto no valor do salário-hora que é de R \$ 8,16 em valores nominais de 2016. Desta forma, o dia de trabalho considerando uma jornada de oito horas vale, em média, $\mathrm{R} \$ 65,28$.

A violência perpetrada pelo parceiro resulta em absenteísmo por parte da mulher vitimada, a qual experimenta queda em sua produtividade no emprego devido aos dias longe do trabalho. "Menores 
durações de emprego significam que as vítimas de violência doméstica terão a sua capacidade econômica diminuída, enfraquecendo a sua capacidade de empoderamento dentro do domicílio, aumentando a sua dependência em relação ao parceiro.” (PCSVDF- Mulher, 2017, p. 13). Durações menores de emprego também significam que as mulheres vítimas de violência terão menos chance de desenvolver uma habilidade específica ou se especializarem em uma área determinada, como consequência serão preteridas nas promoções de carreira.

É inimaginável todas as consequências perpetradas por um problema que ainda nos dias de hoje é naturalizado pela sociedade, é necessário que as pesquisas que vinculam a violência doméstica à economia do país se intensifiquem, na tentativa de demonstrar aos agentes políticos e à própria população que o cenário em que nos encontramos hoje - em que o Brasil ocupa o $79^{\circ}$ lugar no ranking mundial do IDH - tem seus contornos definidos por uma questão erroneamente considerada apenas do foro íntimo da mulher.

\subsection{IMPACTOS DA VIOLÊNCIA DOMÉSTICA NO MERCADO DE TRABALHO}

Na continuidade, a relação proposta nesta seção se dá entre a violência doméstica e o mercado de trabalho - especificamente o setor privado - de modo a evidenciar como esta relação interfere no desenvolvimento econômico do país.

A capacidade laboral da mulher que sofre violência é reduzida de várias maneiras e isso gera impactos negativos nos lucros das grandes e pequenas empresas, além de que "A renda que essas mulheres deixam de ganhar poderia movimentar diversos setores." (PCSVDF-Mulher, 2017, p. 12). Para a pesquisa PCSVD-Mulher, é possível estimar que a violência doméstica tenha um impacto de 5\% no PIB (Produto Interno Bruto) do País.

Para os autores Swanberg, Logan e Macke, no estudo "Intimate Partner Violence, Employment, and The Workplace: Consequences and Future Directions" (2005), as pesquisas que abordam o tema e associam a violência doméstica e o mercado de trabalho podem adotar duas perspectivas: a da vítima, individualmente, e as significativas consequências na saúde da mulher, determinando padrões de mercado de trabalho (participação, horas trabalhadas e salários); e a perspectiva que considera o impacto na capacidade laboral, habilidade e produtividade da vítima no emprego, à nível organizacional.

Em longo prazo, as consequências advindas da violência doméstica têm a capacidade de determinar padrões e históricos de mercado de trabalho inconsistentes, "dinâmicas individuais oscilando entre períodos de emprego curtos e de desemprego longos, subemprego e redução permanente na produtividade e salário" (SWANBERG; LOGAN; MACKE, 2005), e até estabelecendo paradigmas de absenteísmo como abordado na seção anterior. 
Quando se adota a segunda perspectiva e analisa-se a problemática a partir da vítima, um dos principais mecanismos pelo qual a violência doméstica pode afetar a produtividade da mulher é por meio da deterioração de sua saúde.

A violência doméstica pode comprometer as funções cognitivas da mulher tais como
concentração e memória, afetando o desempenho no trabalho (Banyard et al. (2011)).
Além disso, a violelncia doméstica pode afetar negativamente a confiança da mulher
em si mesma, bem como o senso de controle de suas ações e consequências,
impedindo que ela exerça seu trabalho de maneira plena (Stark (2007)). Há outras
consequências negativas da violência doméstica para a saúde mental que podem
afetar indiretamente a capacidade laborativa da mulher como é o caso da depressão
(White e Satyen (2015)), o alcoolismo (Kaysen et al. (2007)) e uso de drogas ilícitas
(Atkinson et al. (2009)). Em casos extremos, a violência doméstica pode levar
também ao comportamento suicida (Devries et al. (2011)). (PCSVDF-Mulher, 2017,
p. 7)

Uma mulher que sofreu ou sofre violência em sua residência e permanece assídua no trabalho, acaba não exercendo suas funções com plenitude, deixando de gerar lucros. Algumas consequências, porém, podem trazer prejuízos perduráveis à saúde da vítima, como o uso contínuo de drogas e álcool, e o desencadeamento de um estado depressivo; podendo levar esta mulher, inclusive, à perda do emprego.

Os resultados da pesquisa PCSVDF-Mulher, 2017, mostram que as mulheres vítimas de violência doméstica nos últimos 12 meses reportam menor frequência no exercício de sua capacidade de concentração, na capacidade de dormir bem, em tomar decisões, além de se sentir frequentemente estressada e menos feliz em comparação com as mulheres não vitimadas pelos parceiros. Tais evidências indicam que a violência doméstica pode deteriorar o estado emocional da mulher, bem como reduzir sua capacidade de concentração e tomada de decisão que são fundamentais no exercício de qualquer atividade no mercado de trabalho.

Outro aspecto relevante que pode estar diretamente relacionado à perda de satisfação com o emprego é a falta de autonomia da mulher vítima de violência doméstica com respeito à sua renda pessoal.

\begin{abstract}
Observa-se que 23\% das mulheres vítimas de violência doméstica nos últimos 12 meses reportaram ter recusado ou desistido de alguma oportunidade de emprego nesse mesmo período de referência porque o parceiro era contra. Enquanto isso, 9\% das mulheres não vitimadas pelos parceiros reportaram ter recusado alguma oportunidade de emprego nos últimos 12 meses. Esse resultado fornece ainda mais respaldo à hipótese de que a violência doméstica deteriora a autonomia da mulher.(PCSVDF- Mulher, 2017, p. 10)
\end{abstract}

É por essa razão que Swanberg, Logan e Macke (2005, p. 8) afirmam ser inconclusivo determinar que a violência tem relação com o status empregada ou desempregada, mas os resultados do estudo confirmam que a violência impacta diretamente na capacidade da mulher de sustentar seus 
empregos a longo prazo. Nitidamente, o mercado de trabalho como é conhecido atualmente é resultado de diversos fatores, um deles é a incansável luta da mulher para, em um primeiro momento ser inserida e, na sequência, alcançar a igualdade de condições entre homens e mulheres. A violência doméstica age consolidando padrões nesse mercado, e a médio e longo prazo esses fatores produzem um capital humano de menor valor que se refletirá no salário dessas mulheres. Significa então que a violência doméstica possui o potencial de diminuir os salários dessas vítimas, o que perpetua o ciclo da violência. Nesse sentido, a atuação do Estado se faz necessária para assegurar as condições de igualdade e o direito da mulher ao trabalho.

\subsubsection{A LEI MARIA DA PENHA E A PROTEÇÃO DO TRABALHO DA VÍTIMA}

Tendo em vista os reflexos da violência doméstica e familiar na vida privada e profissional da vítima, bem como os impactos desta violência no mercado de trabalho e na economia do país, necessário se faz, portanto, buscar alternativas para que, diante das situações oriundas da violência em si ou do cumprimento de medidas de proteção à vítima, a mulher possa ter protegido o seu direito ao trabalho. Afinal, em decorrência da violência praticada, a vítima passa a externar, ainda que involuntariamente, os efeitos das agressões em seu comportamento no ambiente de trabalho.

Os impactos da violência doméstica na vida laborativa da mulher empregada pode resultar em situações de nítido comprometimento das atividades por ela desempenhadas no local de trabalho. Significando dizer que, a influência das agressões na saúde física e mental da mulher terá um efeito sobre o seu rendimento, sobre a sua produtividade, na sua convivência com a equipe de trabalho, com colaboradores, clientes e público de atendimento, na sua assiduidade, habilidades etc. Situações que poderiam acabar culminando em demissão, inclusive por justa causa, sendo uma resposta, por parte do empregador, que se revelaria demasiadamente injusta quando do conhecimento das agressões e do ciclo de violência em que esta mulher está inserida.

Consciente disso, o legislador brasileiro incluiu na Lei n. ${ }^{\circ} 11.340 / 2006$ a previsão de que deverão ser asseguradas às mulheres as condições para o exercício efetivo dos direitos sociais, o que inclui o direito a ter acesso ao trabalho ${ }^{11}$. Assim, analisando os "aspectos trabalhistas" da Lei Maria da Penha, nota-se que a Lei traz o instituto da proteção do trabalho da mulher empregada vítima de violência doméstica e familiar, garantindo-lhe o afastamento das atividades laborativas, ao passo que garante igual direito à manutenção do vínculo empregatício quando necessário for o seu afastamento do local de trabalho.

\footnotetext{
${ }^{11}$ Art. $3^{\circ}$ Serão asseguradas às mulheres as condições para o exercício efetivo dos direitos à vida, à segurança, à saúde, à alimentação, à educação, à cultura, à moradia, ao acesso à justiça, ao esporte, ao lazer, ao trabalho, à cidadania, à liberdade, à dignidade, ao respeito e à convivência familiar e comunitária.
} 
Ao versar sobre a assistência à mulher em situação de violência doméstica e familiar, a Lei estabelece o seguinte:

Art. $9^{\circ} \mathrm{A}$ assistência à mulher em situação de violência doméstica e familiar será prestada de forma articulada e conforme os princípios e as diretrizes previstos na Lei Orgânica da Assistência Social, no Sistema Único de Saúde, no Sistema Único de Segurança Pública, entre outras normas e políticas públicas de proteção, e emergencialmente quando for o caso. [...]

$\S 2^{\circ} \mathrm{O}$ juiz assegurará à mulher em situação de violência doméstica e familiar, para preservar sua integridade física e psicológica:

I - acesso prioritário à remoção quando servidora pública, integrante da administração direta ou indireta;

II - manutenção do vínculo trabalhista, quando necessário o afastamento do local de trabalho, por até seis meses. (grifo nosso).

Da leitura do referido artigo da Lei Maria da Penha, Castilho (2011, p. 235) observa que a partir do conteúdo assistencial previsto as disposições elencadas no art. $9^{\circ}$ podem ser classificadas em três grupos. O primeiro grupo estaria relacionado às políticas públicas de proteção, em especial às políticas voltadas à assistência social, à saúde e à segurança. $\mathrm{O}$ segundo, com referência à proteção no trabalho, "com regras diferenciadas para o caso de a mulher ser servidora pública ou ser empregada em empresa privada.”. E, por fim, o terceiro grupo, dirigido à proteção à saúde. (CASTILHO, 2011).

Assim, reconhecendo a necessidade de a mulher vítima de violência doméstica poder prover o seu próprio sustento a Lei Maria da Penha previu, além do amparo legal na esfera penal e na criação de políticas públicas e ações assistencialistas, a tutela da mulher na esfera trabalhista. Nota-se que tal disposição não tem o condão de estabelecer nenhuma espécie de favorecimento à mulher no mercado de trabalho, mas de buscar o estabelecimento de uma relação de trabalho alicerçada na justiça e na igualdade, tendo em conta a vulnerabilidade da vítima de violência doméstica ou familiar diante de possíveis decisões unilaterais do empregador no transcurso do contrato de trabalho.

Adotando como foco as relações de trabalho no âmbito da iniciativa privada, no art. $9^{\circ}$ da Lei em comento, inciso II do $\S 2^{\circ}$, há um comando dirigido ao empregador para que haja a manutenção do vínculo trabalhista da mulher empregada vítima de violência doméstica. Na prática, segundo Castilho, o empregador só assegurará a manutenção do contrato de trabalho se compelido pelo Judiciário (CASTILHO, 2011, p. 235).

No que tange à finalidade de tal medida - considerada um meio de reforçar e dar efetividade às medidas de proteção à mulher no âmbito da Lei Maria da Penha -, considera-se benéfica quando da necessidade, por exemplo, da adoção de medidas protetivas de urgência à ofendida (Art. 23 da Lei n. ${ }^{\circ}$ 11.340/2006), como o seu afastamento, e de seus dependentes, do lar e o respectivo encaminhamento a programa oficial ou comunitário de proteção de vítimas ou a casas-abrigo. "O exercício da função pública em outro local, pelo acesso prioritário à remoção [servidora pública], ou a manutenção do 
vínculo empregatício por prazo determinado podem ser indispensáveis para dar condições à mulher de retomar sua vida." (CASTILHO, 2011, p. 242).

Considera-se louvável a atitude do legislador em prever uma medida significativa como essa, no entanto, persistem algumas brechas quando da aplicabilidade dessa disposição, pois, entende-se que há lacunas legislativas no que tange à própria natureza do instituto quando analisado e aplicado sob a perspectiva do Direito do Trabalho. Por exemplo, a doutrina diverge se a medida seria uma hipótese de suspensão ou de interrupção do contrato de trabalho, e questiona as suas implicações e repercussões jurídicas no contrato de trabalho, tendo em vista a onerosidade e os encargos que poderiam ser atribuídos ao empregador. Situação que poderia vir a ser motivo de práticas discriminatórias no mercado de trabalho, ensejando uma predileção pela contratação de pessoas do sexo masculino, a fim de se evitar possíveis obrigações dessa natureza.

No entanto, identifica-se que o entendimento prevalecente é o de que seria caso de suspensão e não de interrupção do contrato de trabalho, acarretando o ônus de arcar com o salário da empregada não ao empregador, mas sim ao órgão previdenciário. Na compreensão de Castilho,

\begin{abstract}
A interpretação do inciso II acerca da manutenção do vínculo trabalhista da mulher igualmente enseja dificuldades. Viu-se que no processo legislativo a intenção não foi a de assegurar o pagamento dos encargos trabalhistas, apenas a manutenção do vínculo. Cabe então indagar qual a natureza desse afastamento legal não remunerado para saber as implicações relativamente aos encargos trabalhistas e previdenciários. Em primeiro lugar, é corrente a interpretação que o afastamento configura uma suspensão do contrato de trabalho. Isso significa que o empregador não está obrigado a pagar o salário nem a recolher as contribuições previdenciárias e o FGTS. Explica Sérgio Pinto Marins (2008, p. 458) que "a suspensão envolve a cessação temporária e total da execução e dos efeitos do contrato de trabalho. Na interrupção há a cessação temporária e parcial do contrato de trabalho, porém há a produção de efeitos". Ressalta que "o empregador não poderá, por exemplo, conceder aviso prévio na suspensão do contrato de trabalho" e que, quando o empregado voltar à empresa, "terá direito a todas as vantagens legais ou normativas que forem atribuídas à categoria a que pertence na empresa" (p. 459). (CASTILHO, 2011, p. 243)
\end{abstract}

Existe, portanto, a proteção trabalhista da mulher vítima de violência doméstica e familiar amparada na Lei. Para que não sejam cometidas injustiças ou arbitrariedades e, consequentemente, para que as dificuldades e o sofrimento suportado pela mulher vitimada não sejam intensificados por razões alheias a sua vontade, emerge a possibilidade jurídica de se proteger o trabalho da mulher, tendo em vista ser o trabalho um direito humano, havendo, inclusive, a proteção contra o desemprego prevista no artigo 23 da Declaração Universal dos Direitos Humanos. ${ }^{12}$

\footnotetext{
12 Artigo 23:

1. Todo ser humano tem direito ao trabalho, à livre escolha de emprego, a condições justas e favoráveis de trabalho e à proteção contra o desemprego.

2. Todo ser humano, sem qualquer distinção, tem direito a igual remuneração por igual trabalho.
} 
No Brasil, além da proteção ao trabalho da mulher contida na Lei Maria da Penha, existem outras iniciativas estatais para buscar prevenir a violência e punir o agressor, buscando também reduzir o custo da violência que recai sobre a vítima e sobre o Estado. Nesse sentido, cabe citar a recente alteração no art. $9^{\circ}$ da Lei n. ${ }^{\circ} 11.340 / 2006$ feita pela Lei n. ${ }^{\circ} 13.871 / 2019$, que acrescentou parágrafos ${ }^{13}$ dispondo sobre a responsabilidade do agressor pelo ressarcimento dos custos relacionados aos serviços de saúde prestados pelo Sistema Único de Saúde (SUS) às vítimas de violência doméstica e familiar e aos dispositivos de segurança por elas utilizados.

Outra iniciativa legislativa, consubstanciada no Projeto de Lei do Senado n. ${ }^{\circ} 296 / 2013$, consiste na criação do Auxílio-Transitório Decorrente de Risco Social Provocado por Situação de Violência Doméstica e Familiar Contra a Mulher, porém, ainda está pendente de aprovação. O projeto, em tramitação na Câmara dos Deputados (sob o n. ${ }^{\circ}$ PL 6.296/2013), visa alterar a Lei n. ${ }^{\circ}$ 8.213/1991, que dispõe sobre os Planos de Benefícios de Previdência Social e a Lei Maria da Penha, para a instituição de tal auxílio às mulheres, definindo a caracterização desse benefício nos mesmos moldes do benefício acidentário, propondo, ainda, como uma das fontes de custeio, a criação de uma arrecadação a ser feita pelo agressor.

Medidas como as que foram expostas nas linhas anteriores são necessárias e também urgentes para que seja coibida e punida toda forma de violência contra a mulher. E para que não se permita que, além de suportar as agressões e o desmantelamento da sua vida familiar, a mulher tenha também de ver arruinada a sua vida profissional, a sua autonomia financeira e a sua chance de se desenvolver enquanto ser humano. No mais, não seria justo permitir que, devido à violência sofrida, a mulher tenha de suportar o desemprego e passe a ser dependente economicamente do seu agressor, dificultando ainda mais a sua capacidade de romper com os vínculos; acentuando a violência e motivando a permanência da mulher no ciclo de violência.

Nesse sentido, tomando por base os impactos e os riscos advindos da violência perpetrada contra a mulher, é salutar que o Estado atue na tutela do direito fundamental ao trabalho, uma vez que a mulher vítima de violência doméstica e familiar, nas circunstancias que envolvem a sua posição do

\footnotetext{
$13 \S 4^{\circ}$ Aquele que, por ação ou omissão, causar lesão, violência física, sexual ou psicológica e dano moral ou patrimonial a mulher fica obrigado a ressarcir todos os danos causados, inclusive ressarcir ao Sistema Único de Saúde (SUS), de acordo com a tabela SUS, os custos relativos aos serviços de saúde prestados para o total tratamento das vítimas em situação de violência doméstica e familiar, recolhidos os recursos assim arrecadados ao Fundo de Saúde do ente federado responsável pelas unidades de saúde que prestarem os serviços.

$\S 5^{\circ}$ Os dispositivos de segurança destinados ao uso em caso de perigo iminente e disponibilizados para o monitoramento das vítimas de violência doméstica ou familiar amparadas por medidas protetivas terão seus custos ressarcidos pelo agressor.

$\S 6^{\circ}$ O ressarcimento de que tratam os $\S \S 4^{\circ}$ e $5^{\circ}$ deste artigo não poderá importar ônus de qualquer natureza ao patrimônio da mulher e dos seus dependentes, nem configurar atenuante ou ensejar possibilidade de substituição da pena aplicada.
} 
mercado de trabalho, acaba sendo duplamente castigada pelos efeitos da violência sofrida, na medida em que esta transcende a esfera da vida privada e familiar e alcança a vida profissional.

\section{VIOLÊNCIA DOMÉSTICA E DESENVOLVIMENTO HUMANO}

A Declaração sobre o Direito ao Desenvolvimento, proclamada em 4 de dezembro de 1986 pela Assembleia Geral das Nações Unidas (Resolução n. ${ }^{\circ}$ 41/128), consagrou o desenvolvimento como um direito humano e o conceituou como um direito inalienável, em virtude do qual toda pessoa e todos os povos estão habilitados a participar, contribuir e desfrutar do "desenvolvimento econômico, social, cultural e político, no qual todos os direitos humanos e liberdades fundamentais possam ser plenamente realizados" $\left(\right.$ Art. $\left.1^{\circ}, \S 1^{\circ}\right)$.

No preâmbulo da citada Declaração, consignou-se o reconhecimento da pessoa humana enquanto sujeito central do processo de desenvolvimento, de modo que toda política voltada ao desenvolvimento deve adotar como ponto de referência o ser humano, na qualidade de principal participante e beneficiário do desenvolvimento. Nesse sentido, o Atlas do Desenvolvimento Humano no Brasil $^{14}$, também define o desenvolvimento humano e ratifica a ideia da centralidade na pessoa, inclusive, na ampliação do bem-estar, das liberdades, das capacidades e oportunidades do sujeito.

Da análise dos dados apresentados nas seções anteriores, ficou demonstrado que a violência doméstica e familiar contra a mulher possui significativa parcela de impacto no desenvolvimento econômico do país, seja em razão dos custos gerados pelas projeções da violência doméstica no orçamento do Sistema Único de Saúde (SUS), ou em decorrência do impacto financeiro provocado pela interferência da violência no mercado de trabalho e na vida profissional da mulher vítima. Desta forma, é possível estabelecer um liame entre violência doméstica, desenvolvimento econômico e desenvolvimento humano, tendo em vista que, semelhantemente a um "efeito cascata", as consequências da violência doméstica, grosso modo, debruçam os seus efeitos nefastos sobre a economia do país, que, por sua vez, vem a recair sobre o desenvolvimento humano.

Afinal, a renda que a mulher deixa de obter como contraprestação do seu trabalho - em razão da violência doméstica - significa menos capital em circulação no mercado e, de igual forma, com o possível comprometimento da produção e dos lucros, as empresas também deixam de contribuir para o desenvolvimento econômico do país. Nessa lógica, se forem reduzidos os recursos e as riquezas do país, deficitário será também o investimento em áreas que figuram como essenciais para o desenvolvimento humano, à medida que o "progresso do desenvolvimento humano implica a

\footnotetext{
14 “O Atlas do Desenvolvimento Humano no Brasil engloba o Atlas do Desenvolvimento Humano nos Municípios e o Atlas do Desenvolvimento Humano nas Regiões Metropolitanas. Informações disponíveis no sítio oficial do Atlas Brasil. Disponível em: http://www.atlasbrasil.org.br/2013/pt/o_atlas/o_atlas_/ Acesso em 25 abr. 2020.
} 
capacidade de gerar rendimento e convertê-lo em capacidades, incluindo melhores resultados ao nível da saúde e da educação" (PNUD, 2019, p. 68).

Assim, entende-se que o impacto da violência doméstica no desenvolvimento econômico trará efeitos no desenvolvimento humano do país, em especial, quando analisado o contexto da mulher vítima no mercado de trabalho, haja vista a compreensão de que o trabalho também tem a sua relação com o desenvolvimento humano, constituindo-se em base fundamental para a riqueza das economias e para a riqueza das pessoas (PNUD, 2015). Em outras palavras, "a relação entre o trabalho e o desenvolvimento humano é sinérgica", pois, "o trabalho reforça o desenvolvimento humano." (PNDU, 2015, p. 4).

Convém observar que, embora o conceito de desenvolvimento humano adote a perspectiva de transferir o foco do desenvolvimento para o ser humano, indo além do viés do crescimento econômico por si só, o ciclo utilizado para se medir e avaliar o nível de desenvolvimento humano também inclui a renda. A renda, na concepção do Programa das Nações Unidas para o Desenvolvimento (PNUD), é importante como um dos meios para se alcançar o desenvolvimento humano, mas não como o seu fim, adotando-se, portanto, uma ideia de desenvolvimento conjunto: pessoa e economia.

Deste modo, considerando as características sociais, culturais e políticas que influenciam a qualidade da vida humana, ainda segundo o PNUD, o conceito de desenvolvimento humano é utilizado como a base do Índice de Desenvolvimento Humano (IDH). O IDH, de modo geral, trata-se de "um índice composto que mede as realizações médias em três dimensões básicas do desenvolvimento humano: uma vida longa e saudável, o conhecimento e um padrão de vida digno" (PNUD, 2019, p. 297), servindo de contraponto ao Produto Interno Bruto (PIB). Nessa perspectiva, nota-se que uma das dimensões básicas do desenvolvimento humano é a renda, o que, novamente, vem a corroborar os argumentos delineados ao longo desta seção.

Ademais, outro requisito para a expansão do desenvolvimento humano é a longevidade. E mencionar a importância de se sustentar uma vida longa e saudável é assunto que vai ao encontro do tema, tendo em vista as inúmeras implicações que a violência doméstica traz para a vida e saúde da mulher vítima. Portanto, pensar no ser humano e colocá-lo no centro das discussões para enfrentamento dos percalços do desenvolvimento é também pensar na saúde da mulher vítima de violência doméstica, pois, não deve ser ignorado o fato de que a manutenção da mulher no ciclo de violência segue na contramão da promoção de um padrão qualitativo de saúde física e mental indispensáveis ao pleno desenvolvimento humano.

No mais, quando relacionados os impactos da violência doméstica sobre o desenvolvimento humano, fica evidente que a questão deve ser enfrentada levando em consideração todas as projeções que a violência lança sobre o desenvolvimento humano individual e coletivo, haja vista não ser um 
assunto que começa e que termina dentro das casas das vítimas; não é um problema que se limita ao espaço privado, mas que atinge a esfera pública nas mais críticas dimensões.

\subsection{DESIGUALDADE DE GÊNERO E DESENVOLVIMENTO HUMANO}

Segundo o Relatório do Desenvolvimento Humano 2019 do PNDU - cujo capítulo quatro versa especificamente sobre As Desigualdades de Gênero Além das Médias: entre as normas sociais e os desequilíbrios de poder -, nos países em geral, "as disparidades de género permanecem entre as formas mais persistentes de desigualdade. Dado que estas desvantagens afetam metade da população mundial, podemos argumentar que a desigualdade de género é uma das maiores barreiras ao desenvolvimento humano." (PNDU, 2019, p. 147).

A violência doméstica e familiar contra a mulher tem as suas raízes na desigualdade de gênero. "Há muito que a desigualdade de género está associada a normas sociais discriminatórias persistentes, que ditam os papéis sociais e as relações de poder entre os homens e as mulheres no seio da sociedade" (PNDU, 2019, p. 152). Com isso, as mulheres sofrem entraves nas estruturas socioeconômicas e políticas, "devido a preconceitos subjacentes às convicções sociais, normas e valores culturais" (PNUD, 2015, p. 76). Portanto, é fundamental discutir a associação intrínseca entre desigualdade de gênero e desenvolvimento humano.

A Lei n. ${ }^{\circ} 11.340 / 2006$, no art. $2^{\circ}$, dispõe que "toda mulher, independentemente de classe, raça, etnia, orientação sexual, renda, cultura, nível educacional, idade e religião, goza dos direitos fundamentais inerentes à pessoa humana", e que devem ser "asseguradas as oportunidades e facilidades para que a mulher possa viver sem violência, preservar sua saúde física e mental e seu aperfeiçoamento moral, intelectual e social" (grifo nosso). Assim, de forma correlata, a Lei Maria da Penha apresenta um conteúdo que se amolda ao conceito de desenvolvimento humano, à medida que dispõe sobre o processo de ampliação de escolhas, de capacidades e de oportunidades da mulher.

$\mathrm{Na}$ esteira do que foi apresentado no RDH 2019 sobre o desenvolvimento humano da mulher e sobre as implicações da violência neste desenvolvimento, ficou esclarecido que a desigualdade de gênero é fator que contribui tanto para a configuração da violência perpetrada contra a mulher, quanto para a acentuação das desigualdades sociais. Afinal,

A violência contra as mulheres é uma das formas mais cruéis de descapacitação das mesmas. Amplificando a desigualdade, tem lugar ao longo de todo o ciclo de vida, em diferentes espaços - famílias, instituições, espaços públicos, esfera política e Internet - em todas as sociedades, no seio de todos os grupos socioeconómicos e em todos os níveis de instrução. É, além disso, o reflexo das mesmas normas sociais que legitimam o assédio e a discriminação. (PNDU, 2019, p. 166) 
Em outras palavras, "a desigualdade de género está correlacionada com uma perda no desenvolvimento humano devido à desigualdade" (PNDU, 2019, p. 147). Ademais, constata-se que o desenvolvimento humano das mulheres está atrelado a fatores socioeconômicos responsáveis por delinear o seu status social, incluindo a necessidade de capacitação em diferentes domínios.

O género é um fator global da desigualdade em termos de autonomia humana, segurança física e capacitação social, económica e política. O desenvolvimento humano das mulheres depende de fatores socioeconómicos favoráveis, como a capacidade de prosseguir uma carreira, alcançar a estabilidade do rendimento e auferir vencimentos comparáveis aos dos homens. A capacitação das mulheres nos domínios da saúde, da educação, das oportunidades de rendimento, da participação e dos direitos políticos pode modificar a tomada de decisões sociais e o desenvolvimento nesta área. (PNDU, 2019, p. 167).

$\mathrm{O}$ fato de as mulheres serem confrontadas a sustentar uma carga de expectativas sociais convencionais que, por vezes, lhes retiram a igualdade e a liberdade na tomada de decisões, faz com que o objetivo de se alcançar o desenvolvimento humano seja comprometido e dificultado pela desigualdade persistente. Tendo em vista que a desigualdade de gênero e a consequente violência restringem as oportunidades de escolha, as capacidades e repercutem de maneira negativa sobre as liberdades básicas da mulher, e que o desenvolvimento humano está relacionado com "a expansão das liberdades substantivas e das opções", em oposição às “escolhas limitadas ou mesmo trágicas com que as mulheres se defrontam" (PNDU, 2019, p. 158).

Nesse mesmo sentido, ainda segundo o Relatório do Desenvolvimento Humano (2019, p. 164), a expansão das oportunidades das mulheres, a promoção da sua participação econômica, social e política, e a melhoria do seu acesso à proteção social, ao emprego e aos recursos naturais tornam as economias mais produtivas, sendo tipos de investimentos que reduzem a pobreza e a desigualdade, contribuindo para a formação de sociedades mais pacíficas. Cabendo, portanto, cuidar para que sejam suplantadas as construções sociais fundadas em normas discriminatórias que reforçam os estereótipos associados aos gêneros e que retardam o processo de mudança, a fim de que, igualmente, haja a desconstrução das desigualdades que "são intensas, generalizadas e subjazem à distribuição desigual do progresso ao nível do desenvolvimento humano entre os escalões de desenvolvimento socioeconómico.” (PNDU, 2019, p. 148).

Sabe-se que as "ações, atitudes e condutas violentas são desencadeadas por relações desiguais de poder que ditam papéis em função do género no interior dos agregados familiares” (PNUD, 2019, p. 166). Por isso, devem ser envidados esforços no combate às desigualdades de gênero e à violência doméstica e familiar contra a mulher, principalmente por se ter conhecimento de que "país algum atingiu um baixo nível de desigualdade, em termos de desenvolvimento humano, sem moderar a perda decorrente da desigualdade de género." (PNUD, 2019, p. 148). 
O Relatório do Desenvolvimento Humano (2019, p. 149), apontou que "quanto maior for a perda devido à desigualdade de género, maior é a desigualdade em termos de desenvolvimento humano". Assim, à luz da realidade compartilhada, é conclusivo que a violência doméstica tem implicações negativas no desenvolvimento humano individual e coletivo. A alternativa, portanto, é buscar a superação dos obstáculos impostos pelas desigualdades de gênero, pois, somente assim a mulher terá a oportunidade de exercer livremente o seu poder de escolha, as suas capacidades e domínios, passando da condição de vítima de violência para a condição de protagonista de sua própria história; atuando na construção de sua autonomia e independência, e podendo, assim, emancipar-se de toda forma de violência que esteja impossibilitando o seu desenvolvimento enquanto pessoa.

\section{CONSIDERAÇÕES FINAIS}

Após investigados e demonstrados os impactos da violência doméstica e familiar contra a mulher a partir de uma dimensão econômica e de desenvolvimento humano, a presente pesquisa permite apontar como resultado e, portanto, como conclusão, a ideia de que há intrínseca associação entre a violência doméstica, o desenvolvimento econômico e o desenvolvimento humano, relação que se extrai da análise de dados quantitativos que apontam os custos da violência para o país. A realidade configurada pela violência não é indicador positivo para o desenvolvimento em nenhum sentido, e a violência que elege como principal vítima as mulheres, torna essa realidade ainda mais desafiadora devido à gravosa repercussão que a violência tem sobre os domínios da esfera pública e privada.

Não bastassem os efeitos nefastos que a violência doméstica produz na vida da mulher vítima, essa prática possui, ainda, uma significativa parcela de impacto no desenvolvimento econômico do país, seja em razão dos custos gerados pelas projeções da violência doméstica no orçamento do Sistema Único de Saúde (SUS), ou em decorrência do impacto financeiro provocado pela interferência da violência no mercado de trabalho e na vida profissional da mulher vítima.

A violência doméstica, no Brasil, é uma conduta coibida e punida nos termos da Lei n. ${ }^{\circ} 11$. 340/2006. Esta lei traz disposições que vão ao encontro da necessária proteção dos direitos básicos, das liberdades e das capacidades das mulheres, visando à ampliação das oportunidades, à promoção da participação econômica, social e política, e à melhoria do acesso ao mercado de trabalho. Valores e garantias indispensáveis à superação da desigualdade de gênero que ainda persiste e que restringe sobremaneira as oportunidades de escolha da mulher, favorecendo a constituição de um cenário de subjugação, discriminação e violência.

Do mesmo modo e, por fim, ao combinar a análise da violência doméstica sob o viés econômico e do desenvolvimento humano, constata-se que os impactos adjacentes à violência se lançam sobre todas as esferas da sociedade. Assim, é conclusivo que, embora as consequências sejam devastadoras 
para a mulher, os desdobramentos da violência doméstica e familiar perpetrada contra a mulher extrapolam os limites da vida privada da vítima, alcançando muito mais que as paredes da casa onde a violência acontece. A partir disso, e por meio da compreensão de que a violência doméstica é fator de influência que se projeta nas mais variáveis áreas do desenvolvimento econômico e do desenvolvimento humano, espera-se que pesquisas e ações nesse sentido sejam intensificadas.

\section{REFERÊNCIAS}

AZAMBUJA, Mariana Porto Ruwer de; NOGUEIRA, Conceição. Violência de gênero: uma reflexão sobre a variabilidade nas terminologias. Revista Saúde em Debate. Rio de Janeiro, v. 31, n. 75/76/77, p. 97-106, jan./dez. 2007

BRASIL. Código Penal. Decreto-Lei n. 2. 848, de 7 de dezembro de 1940. Disponível em: http://www.planalto.gov.br/ccivil_03/decreto-lei/del2848compilado.htm Acesso em: 10 abr. 2020.

BRASIL. Constituição da República Federativa do Brasil, 1988. Disponível em: http://www.planalto.gov.br/ccivil_03/constituicao/constituicao.htm Acesso em 18 abr. 2020.

BRASIL. Lei n. 11.340/2006. Cria mecanismos para coibir a violência doméstica e familiar contra a mulher. Brasília. 2006. Disponível em: http://www.planalto.gov.br/ccivil_03/_ato20042006/2006/lei/111340.htm Acesso em 18 abr. 2020.

BRASIL. Lei n. 13. 871/2019. Altera a Lei $\mathrm{n}^{\circ} 11.340$, de 7 de agosto de 2006. Disponível em: http://www.planalto.gov.br/ccivil_03/_Ato2019-2022/2019/Lei/L13871.htm Acesso em 18 abr. 2020.

BRASIL. Lei das Contravenções Penais. Decreto-Lei n. 3.688, de 3 de outubro de 1941. São Paulo. Revista dos Tribunais. 2013.

CARNEIRO, Alessandra Acosta; FRAGA, Cristina Kologeski. A Lei Maria da Penha e a proteção legal à mulher vítima em São Borja no Rio Grande do Sul: Da violência denunciada à violência silenciada. Revista Serviço Social e Sociedade, São Paulo, n. 110, p. 369-397, abr./jun. 2012.

CASTILHO, Ela Wiecko V. de. Da Assistência à Mulher em Situação de Violência Doméstica e Familiar - Artigo $9^{\circ}$. In: CAMPOS, Carmen Hein de. (org). Lei Maria da Penha comentada em uma perspectiva jurídico-feminista. Rio de Janeiro: Editora Lumen Juris, 2011.

COMISSÃO INTERAMERICANA DE DIREITOS HUMANOS. Convenção de Belém do Pará. Convenção Interamericana para Prevenir, Punir e Erradicara Violência contra a Mulher, 1994. Disponível em: http://www.cidh.org/Basicos/Portugues/m.Belem.do.Para.htm Acesso em 15 abr. 2020.

CONSELHO DA EUROPA. Convenção de Istambul. Convenção do conselho da Europa para a prevenção e o combate à violência contra as mulheres e a violência doméstica. Istambul, 2014.

COPEVID - Comissão Permanente de Combate à Violência Doméstica e Familiar contra a mulher, do grupo Nacional de direitos humanos do Ministério Público. Disponível em: 
http://www.mpce.mp.br/wp-content/uploads/2015/12/ENUNCIADOS-COPEVID-2018.pdf Acesso em 18 nov. 2019

CUNHA,Rogério Sanches; PINTO,Ronaldo Batista. Violência doméstica: Lei Maria da Penha 11.340/2016: comentada artigo por artigo. São Paulo, Revista dos Tribunais, 2008.

DIAS, Maria Berenice. A Lei Maria da Penha na Justiça: A efetividade da Lei 11.340/2006 de combate à violência doméstica e familiar contra a mulher. São Paulo. Editora Revista dos Tribunais. $4^{\mathrm{a}}$ ed. 2015.

ESPANHA. Lei Orgânica $\mathbf{n}^{\mathbf{0} 1}$, de 28 de dezembro de 2004 . Disponível em: https://www.boe.es/buscar/act.php?id=BOE-A-2004-21760 Acesso em 19 de ago. 2019.

FONAVID. Fórum Nacional de Juízas e Juízes de Violência Doméstica e Familiar Contra a Mulher - ENUNCIADOS. 2018. Disponível em: https://www.amb.com.br/fonavid/enunciados.php Acesso em 13 jan. 2020

FÓRUM DE SEGURANÇA PÚBLICA. Segurança Pública em Números, 2018. Disponível em: http://www.forumseguranca.org.br/wp-content/uploads/2019/02/Infografico_an12_atualizado.pdf Acesso em 18 abr. 2020.

GREGORI, Maria Filomena. Deslocamentos Semânticos e hibridismos: sobre os usos da noção de violência doméstica contra a mulher. Revista Brasileira de Ciências Criminais, São Paulo, nº 48, p. 250, maio-jun 2004.

HOEFFLER, Anke; FEARON, James.Conflict and Violences:Benefits and Costs of the Conflict andViolence Targets for the Post-2015 Development Agenda. Copenhagen Consensus, 2014.

KATO, Shelma Lombardi de. Lei Maria da Penha: uma lei constitucional para enfrentar a violência doméstica e construir a difícil igualdade de gênero. Revista Brasileira de Ciências Criminais, São Paulo, v. 71, p. 268, mar. 2008.

LAVORENTI, Wilson. Violência e discriminação contra a mulher. Tratados internacionais de proteção e o direito penal brasileiro. Tese (Doutorado em Direito Penal). Pontifícia Universidade Católica de São Paulo, São Paulo, 2007.

LOPES, Adriana Galvão; MACHADO, Isadora Vier; VENÂNCIO, Karen Eduarda Alves; LESSA, Letícia de Matos. Lei Maria da Penha: a importância das políticas de abrigamento no contexto de enfrentamento às violências contra a mulher. Revista Direitos Humanos e Democracia. Unjuí. Programa de Pós Graduação Strictu Sensu da Unjuí. Ed Unjuí. Nº 7. Jan/jun. p.172 - 199. 2016.

MORRISON, R. Andrew; BIEHL, Maria Bielo. El costodel silencio: violencia doméstica em las Americas. Inter-American Development Bank. Washington, DC. 1999.

NATIONAL CENTER FOR INJURY PREVENTION AND CONTROL. Costs of Intimate Partner Violence Against Women in the United States. Atlanta (GA): Centers for Disease Control and Prevention; 2003.

NORONHA, E. Magalhães. Direito Penal. 4 ed., v.3, São Paulo: Saraiva, 1969. 
ONU. Declaração Sobre o Direito ao Desenvolvimento, 1986. Disponível em: http://www.direitoshumanos.usp.br/index.php/Direito-ao-Desenvolvimento/declaracao-sobre-odireito-ao-desenvolvimento.html Acesso em 02 abr. 2020.

ONU. Declaração Universal dos Direitos Humanos, 1948. Disponível em: https://nacoesunidas.org/direitoshumanos/declaracao/ Acesso em 03 abr. 2020.

ONU. Organização das Nações Unidas. ONU alerta para os custos da violência contra as mulheres no mundo, 2017. Disponível em: http://www.onumulheres.org.br/noticias/onu-alerta-para-os-custosda-violencia-contra-as-mulheres-no-mundo/ Acesso em 02 abr. 2020.

PCSVDF-Mulher. Pesquisa de Condições Socioeconômicas e Violência Doméstica e Familiar contra a Mulher. Fortaleza, 2017. Disponível em http://www.onumulheres.org.br/wpcontent/uploads/2017/11/violencia_domestica_trabalho_ago_17.pdf. Acesso em 02 fev 2020.

PNDU. Programa das Nações Unidas para o Desenvolvimento. Relatório do Desenvolvimento Humano 2019. Além do rendimento, além das médias, além do presente: Desigualdades no desenvolvimento humano no século XXI. Disponível em: http://hdr.undp.org/sites/default/files/hdr_2019_pt.pdf Acesso em 28 mar. 2020.

PNDU. Programa das Nações Unidas para o Desenvolvimento. Relatório do Desenvolvimento Humano 2015. O Trabalho como Motor do Desenvolvimento Humano. Disponível em: http://hdr.undp.org/sites/default/files/hdr_2015_report_pt.pdf Acesso em 01 abr. 2020.

RIBERO, Rocio; SÁNCHEZ, Fábio. Determinants, Effects and Costs of Domestic Violence.CEDE. Jun. 2005.

SCARENCE FERNANDES, Valérie Diez. Lei Maria da Penha: O processo penal no caminho da efetividade. São Paulo. Atlas. $1^{\text {a }}$ ed. 2015.

SENADO FEDERAL. Projeto de Lei do Senado no 296 de 2013. Para instituir o auxílio-transitório decorrente de risco social provocado por situação de violência doméstica e familiar contra a mulher. Disponível em: https://www25.senado.leg.br/web/atividade/materias/-/materia/113732 Acesso em 03 abr. 2020.

TELES, M. A. de A.; MELO, M. de. O que é violência contra a mulher. São Paulo: Brasiliense, 2003.

Trabalho recebido em 16 de maio de 2020

Aceito em 29 de junho de 2021 